\title{
A INCIDÊNCIA DA CLASSIFICAÇÃO INDICATIVA COMO GARANTIA DA EFETIVIDADE DOS DIREITOS HUMANOS NAS DECISÕES DOS TRIBUNAIS
}

\author{
Rodney Rodrigues de Souza \\ Aluno do Curso de Direito da FA7. Monitor da Disciplina \\ de Direito Penal III. \\ rodney.rrs@gmail.com
}

\section{INTRODUÇÃO}

A Constituição Federal de 1988, ao instituir o Estado Democrático de Direito e todos os seus princípios basilares, outorga à União - em seu art. 21, XVI - o exercício da "classificação, para efeito indicativo, de diversões públicas e de programas de rádio e televisão" e, ao mesmo tempo, garante a absoluta prioridade aos direitos da criança e do adolescente: "É dever da família, da sociedade e do Estado assegurar à criança, ao adolescente e ao jovem, com absoluta prioridade, o direito à vida, à saúde, à alimentação, à educação, ao lazer, à profissionalização, à cultura, à dignidade, ao respeito, à liberdade e à convivência familiar e comunitária..." (Art. 277, CF).

Como norma constitucional processual, a classificação indicativa sustenta-se com base em dois princípios de grande valor social: o princípio da proteção integral à criança e ao adolescente e o princípio da liberdade de expressão. Isto posto, o presente trabalho objetiva relatar a análise parcial da pesquisa em desenvolvimento sobre a incidência garantista da classificação indicativa nas decisões do Judiciário brasileiro, pormenorizando os avanços da tutela jurisdicional na proteção da criança e do adolescente em face dos meios de comunicação, principalmente, a televisão.

\section{Atuação Judicial e a ClassificaÇão Indicativa}

A Classificação Indicativa integra o Programa Nacional de Direitos Humanos (PNDH) e, conforme salienta o prof. Antonio Jorge Pereira Junior, ela "é meio de fornecer informação ao cidadão acerca do conteúdo dos programas vinculados na televisão, antes de ele tomar contato com o conteúdo que será transmitido. Para controle posterior do eventual abuso há a tutela administrativa - âmbito do Ministério das Comunicações - e há a tutela judicial.” (PEREIRA JÚNIOR, 2011, p. 270). A necessidade da tutela judicial vem crescendo nos últimos anos e tornando-se cada vez mais necessária para a proteção da criança e do adolescente. Cabe à sociedade garantir a proteção integral 
desses indivíduos que estão em desenvolvimento físico, mental, espiritual e social (ECA, art. $3^{\circ}$ ), logo, o judiciário não poderia abster-se de, quando provocado, tutelar com absoluta prioridade os direitos especiais inerentes à criança e ao adolescente.

\section{Tutela Jurisdicional: Ação Civil Pública}

Cumpre, agora, revelar como se deu a tutela jurisdicional em face das principais ações judiciais movidas contra emissoras de televisão por ofensas aos direitos e às garantias constitucionais da criança e do adolescente, sob a perspectiva da classificação indicativa como garantia da efetividade dos direitos humanos.

\subsection{Ação Civil Pública contra a TV Globo (2000)}

A ação civil pública movida pelo Ministério Público, no ano 2000, contra a TV Globo é uma das peças judiciais mais importantes e que inauguram, com excelência, a proteção ao público infantojuvenil.

A novela Laços de Família, em horário inapropriado, exibia conteúdo diverso do indicado pelo órgão de classificação do Ministério da Justiça. As cenas eram inapropriadas para menores de 14 anos, com restrição de exibição para após as 21 horas, no entanto a emissora iniciava a exibição às $20 \mathrm{~h} 30$. Outro fato que se ponderou na decisão foi a existência de atores mirins que atuavam em cenas consideradas violentas.

Em 2004, o STJ proibiu que a novela Laços de Família fosse reprisada, às 14:30, pela emissora mesmo esta alegando que editaria as cenas e adaptaria ao horário da exibição. No processo do ano 2000, entendeu o Superior Tribunal que:

Embora os pais, no exercício do pátrio poder, devam orientar seus filhos quanto aos programas inadequados às suas faixas etárias, o aviso de classificação é OBRIGATÓRIO para que se faça a respectiva seleção do que é permitido para cada idade, até porque os genitores, no atual contexto da vida de uma cidade grande como o Rio de Janeiro, não estão em tempo integral em suas residências para efetuar tal controle. Inúmeras são as manifestações na área de psicologia infantil que apontam o excesso de violência e cenas de sexo na televisão como fatores influenciadores para a agressividade, desvio e abusos sexuais na infância e na juventude. (STJ, Medida Cautelar nº 3.339-RJ (2000/0132945-6), Rel. Min. Antônio de Pádua Ribeiro).

\subsection{Ação Civil Pública contra a Rede MTV (2002)}

O Ministério Público de São Paulo, em 2002, ajuizou uma ação civil pública em face da MTV Brasil. Segundo a ação, a perícia técnica detectou “mensagens subliminares, consistentes em cenas de sadomasoquismo" veiculadas em um clipe da emissora que era exibido em horário inapropriado, mais especificamente, em horário com grande número de público juvenil. O caso não obteve decisão judicial final dado o acordo entre a emissora e o Ministério Público. A emissora comprometeu-se de, além de retirar do ar o clipe em questão, promover ativamente os direitos da criança e do adolescente em sua programação.

\subsection{Ação Civil Pública contra o SBT (2002)}

O SBT, emissora que exibe o programa Domingo Legal nas tardes de domingo, foi alvo de ação civil pública arguida pelo Ministério Público de São Paulo em setembro de 2002, pelo 
fato de, por volta das 18 horas, ter veiculado sem classificação prévia e sem restrições, imagens de nudez em que mostravam genitais e cenas de insinuações sexuais, agravados pelos comentários inapropriados com conotação sexual do apresentador do programa.

\subsection{Ação Civil Pública contra a Rede TV! (2005)}

Entre os dias 12 de dezembro de 2005 e 20 de janeiro de 2006, a Rede TV!, após decisão da $2^{\text {a }}$ Vara Federal da Subseção Judiciária de São Paulo, foi obrigada a transmitir, em substituição ao programa Tarde Quente, do apresentador João Kleber, uma série de 30 programas educativos, destinados ao público infantojuvenil e de promoção dos direitos humanos. Conforme arguiu o Ministério Público e outras organizações da sociedade civil, o referido programa violava direitos fundamentais ao exibir cenas de humilhação de pessoas simples e instigava a violência contra determinados grupos sociais.

\section{Considerações Finais}

Após parcial análise, conclui-se que a tutela judicial, através da ação civil pública, tem eficácia na reparação dos danos causados aos interesses da criança e do adolescente. Resta analisarmos ainda como essas primeiras decisões dos tribunais interferiram e modificaram a conjuntura atual da mídia na proteção dos direitos infantojuvenis.

\section{REFERÊNCIAS}

BARBOSA, Bia. et al. Direitos de Resposta: a sociedade civil ocupa a TV!. In: Classificação Indicativa no Brasil: Desafios e Perspectiva. Brasília: Secretaria Nacional de Justiça, 2006. p. 263-277.

BRASIL. JUSTIÇA FEDERAL SUBSEÇÃO DE SÃO PAULO, Ação Civil Pública nº 2005.61.00.24137-3 - Rede TV - programa contrário aos direitos humanos e aos interesses da criança. Ano: 2005.

. SUPERIOR TRIBUNAL DE JUSTIÇA, Medida Cautelar n 3.339 - Rio de Janeiro (2000/0132945-6), Rel. Min. Antonio de Pádua Ribeiro - Os direitos da criança e do adolescente e a novela Laços de Família.

. TRIBUNAL DE JUSTIÇA DO ESTADO DE SÃO PAULO, Ação Civil Pública nº 02.201.689-9 - Rede MTV - propaganda subliminar de conteúdo sexual. Ano: 2002.

. TRIBUNAL DE JUSTIÇA DO ESTADO DE SÃO PAULO, Ação Civil Pública $\overline{\mathrm{n}^{\circ} 000}$.02.902.665. Ano: 2002 .

CASTRO, Daniel. Em liminar, juiz proíbe a exibição de cenas de sexo e de genitálias no SBT. Disponível em: <http://www1.folha.uol.com.br/fsp/ilustrad/fq1110200239.htm>. Acesso em: 8 Nov. 2014.

JUSBRASIL: STJ - Agravo regimental na medida cautelar: agrg na mc $11721 \mathrm{mt}$ 2006/0135636-8. Disponível em: < http://stj.jusbrasil.com.br/jurisprudencia/9054628/agravoregimental-na-medida-cautelar-agrg-na-mc-11721-mt-2006-0135636-8/inteiro-teor-14234024>. Acesso em: 08 nov. 2014. 
MINISTÉRIO PÚBLICO-RS: Infração Administrativa. Disponível em: < http://www.mprs. mp.br/infancia/jurisp/idt263.htm>. Acesso em: 08 nov. 2014.

OBSERVATÓRIO DA IMPRENSA. Laços de Família pode sair do ar. Nov. 2000.

Disponível em: < http://observatoriodaimprensa.com.br/news/showNews/qtv201120007.htm>. Acesso em: 8 nov. 2014.

PEREIRA JUNIOR, Antonio Jorge. Direitos da criança e do adolescente em face da TV. São Paulo: Saraiva, 2011.

REVISTA CONSULTOR JURÍDICO. Juiz manda MTV retirar clipe do ar e indenizar telespectadores. Nov. 2002. Disponível em: <http://www.conjur.com.br/2002-nov-05/juiz manda_emissora_retirar_clipe_institucional_ar>. Acesso em: 8 Nov. 2014.

ROMÃO, José Eduardo Elias. A nova Classificação Indicativa: construção democrática de um método. Classificação Indicativa no Brasil: Desafios e Perspectiva. Brasília: Secretaria Nacional de Justiça, 2006. p.17-48.

VALE, Ionilton Pereira do. As Dimensões dos Direitos Humanos Fundamentais. São Paulo: ABC, 2006. 